\title{
Democratic Inefficiency? Regime Type and Suboptimal Choices in International Politics
}

\section{Citation}

Bas, M. A. 2012. "Democratic Inefficiency? Regime Type and Suboptimal Choices in International Politics." Journal of Conflict Resolution 56 (5) (May 30): 799-824. doi:10.1177/0022002712445737.

\section{Published Version}

doi:10.1177/0022002712445737

\section{Permanent link}

http://nrs.harvard.edu/urn-3:HUL.InstRepos:22547792

\section{Terms of Use}

This article was downloaded from Harvard University's DASH repository, and is made available under the terms and conditions applicable to Open Access Policy Articles, as set forth at http:// nrs.harvard.edu/urn-3:HUL.InstRepos:dash.current.terms-of-use\#OAP

\section{Share Your Story}

The Harvard community has made this article openly available.

Please share how this access benefits you. Submit a story.

Accessibility 


\title{
Democratic Inefficiency? \\ Regime Type and Sub-optimal Choices in International Politics
}

\author{
Muhammet A. Bas * \\ Department of Government \\ Harvard University
}

Word Count: 10,951

*My thanks to Elena McLean, Curtis Signorino, Hein Goemans, Randall Stone, and David Carter for valuable comments. I also thank the editor and the anonymous reviewers. All errors remain my own. Replication materials are available at the JCR website. 


\begin{abstract}
This paper examines the relationship between regime type and decision-makers' tendency to make sub-optimal choices in international crises. To test hypotheses on the optimality of democratic foreign policy, I use a novel statistical measure of suboptimality in foreign policy behavior. This estimator builds on Signorino's statistical strategic models to allow for actor-level variation in deviations from optimal behavior in a strategic setting. An analysis of the international disputes from 1919 to 1999 shows that democratic leaders have a greater tendency to choose policies not optimal for their citizens than do non-democratic leaders.
\end{abstract}


Decision, activity, secrecy, and despatch will generally characterize the proceedings of one man in a much more eminent degree than the proceedings of any greater number; and in proportion as the number is increased, these qualities will be diminished.

Alexander Hamilton, Federalist No.70

Are democratic leaders competent foreign policy-makers? Do democratic politics facilitate or hinder optimal foreign policy choices? There is a centuries-old debate in political science concerning the relationship between regime type and the quality of foreign policy choices. Part of the literature has argued that democratic foreign policy is more likely to be sub-optimal, as democratic leaders face difficulties in the implementation of foreign policy due to domestic constraints, while autocratic regimes have fewer difficulties because of the absence or weakness of these constraints (de Tocqueville 1988, Kennan 1950, Gartzke \& Gleditsch 2004). On the opposite end, scholars have argued that domestic constraints and checks and balances improve the quality of foreign policy because they ensure that the executive and government bureaucrats are competent and perform their duties appropriately (Waltz 1967).

For the past two centuries, there was no clear solution to this debate. The two opposing groups of prominent scholars have talked past each other. A major part of the reason was that there was no clear and objective way to assess who is right and who is wrong. In particular, no one has ever offered a systematic way of empirically evaluating the competing claims of these two views.

In this paper, I offer a solution. I propose a novel statistical measure of sub-optimality in foreign policy to test, for the first time, the competing theories on the optimality of democratic foreign policy. This statistical estimator builds on Signorino (1999)'s statistical strategic models to allow for actor-level variation in deviations from optimal behavior. This statistical tool should have wide application areas in different subfields of political science. 
In international relations, the tools provided will help classify - albeit probabilistically - what is optimal, and what is sub-optimal in different foreign policy areas.

My findings suggest that, compared to their autocratic counterparts, democratic leaders are more likely to choose policies that are not optimal for their citizens during international crises. I demonstrate this effect in the context of dyadic international conflict situations during the period after World War I. The reasons for choosing this particular foreign policy area are that, first, militarized disputes are one of the more important and salient foreign policy areas for which the public might have a strong preference, and in which leaders' choices might affect their future office prospects. Second, apart from their potentially large economic or environmental costs, sub-optimal choices in a military conflict might directly or indirectly result in a large number of unnecessary deaths. Therefore, a better understanding of the sources of these choices is important. Third, this is one of the most active areas of substantive research in international relations, and interstate conflict data are available for a larger set of countries and for a longer time period than data on other policy areas.

The next section gives a definition of sub-optimality in foreign policy, provides an overview

of the literature on the link between regime type and foreign policy optimality, and derives testable hypotheses. I then present the data and methods utilized to answer the following questions: what factors affect decision-makers' tendency to choose sub-optimal policies for their citizens in crisis situations? Are democratic leaders more likely to make sub-optimal choices in international politics? The final section presents and discusses the results from the empirical analysis.

\section{What is sub-optimal, and for whom?}

Sub-optimality of foreign policy choices, the main topic of this study, remains understudied in the international relations literature. With respect to government policies, Tuchman (1984) 
defines folly as the pursuit of policies contrary to the self-interest of the constituency or the state involved. Similarly, qualifying a choice as sub-optimal presupposes that there is a better, optimal alternative that should have been chosen. Optimality, however, is a relative concept. What is optimal for an actor may not be optimal for others. In this paper, I parallel Tuchman's definition to define sub-optimality with respect to constituencies' interests in a given foreign policy issue.

How do we define an optimal policy for citizens? Ultimately, a policy is an instrument that policy-makers use to achieve a goal. When we define optimality from the perspective of the public, the goal may be to maximize national security, material benefits to the population from the crisis interaction, to minimize the loss of life, to maintain national prestige or a combination of all or a subset of these. For simplicity of exposition, assume that the goal is to maximize national security only. Because no policy is a perfect instrument, a given policy might potentially lead to different outcomes, which might help or hinder achieving national security. For instance, US sending troops to Afghanistan was a policy intended to enhance US security, but the outcome may be as desired as eliminating the terror threat completely, but also unwanted, such as leading to further terrorist attacks. Since there is usually some uncertainty about the outcome resulting from a policy, decisionmakers will shape their expectations about a policy by taking into account the costs of its implementation, the probability of each potential outcome occurring, and the extent to which each potential outcome serves the policy goal - i.e. enhancing national security. At the end, the optimal policy for the citizens is the one that maximizes national security based on such an expectation. In this sense, a policy is sub-optimal for the public, if there is another policy that is more likely to serve the intended goal of national security.

More formally, I assume that states have objective utility functions to be maximized that define their population's preferences in a crisis. This utility might have different components. 
Following the vast empirical literature on international conflict that treats states as expected utility maximizing actors, we can use factors like relative military capabilities, alliance membership, alliance portfolio similarity, regime type and regime similarity to approximate this utility shaping constituencies' preferences in a crisis against an opponent state. An optimal foreign policy would maximize this utility function. Accordingly, a sub-optimal foreign policy choice implies that there exist other policy choices that would make the citizenry better off.

Selection of foreign policies is made by leaders, and thus it is leaders' choices that may result in sub-optimal outcomes for their citizens. ${ }^{1}$ Why do leaders make choices that are sub-optimal for their population in international politics? It has been argued in the literature that having a democratic regime and leaders subject to the control of others might create difficulties in foreign policy decision-making. The age-old debate about the optimality of democratic foreign policy starts with Alexander Hamilton. In The Federalist Papers, no. 70, Hamilton lists the benefits of having a single, strong executive. He argues that having such an executive is essential for the protection of the community against foreign attacks. He also posits that making the executive subject to the control and co-operation of others will result in a "feeble execution of government" (Hamilton, Madison \& Jay 1961). de Tocqueville (1988) discusses the same issue in his Democracy in America. He contends that democracy's good governance qualities are irrelevant in foreign policy, which requires coherence and long term planning:

Foreign policy does not require the use of any of the good qualities peculiar to democracy but does demand the cultivation of almost all those which it lacks. Democracy favors the growth of the state's internal resources; it extends comfort and develops public spirit, strengthens respect for law in the various classes of society, all of which things have no more than an indirect influence on the 
standing of one nation in respect to another. But a democracy finds it difficult to coordinate the details of a great undertaking and to fix on some plan and carry it through with determination in spite of obstacles. It has little capacity for combining measures in secret and waiting patiently for the result. Such qualities are more likely to belong to a single man or to an aristocracy (de Tocqueville 1988, p.228-229).

More recently, on the other side of the debate, Waltz (1967) argues that democratic foreign policy has better qualities. He talks about the virtues of having a legislative body as a restraint upon the executive power in foreign policy. To emphasize the necessity of a constraint on the executive and bureaucracy in order to test their competence, he gives the example of an ambassador-designate to Ceylon who did not know the name of the country's prime minister. "It is well to have officials interrogated and their performance surveyed by a body whose approval and disapproval makes a difference. The harmful effects of the process are offset if the difficult and important task of checking and prodding a bureaucracy of immense size are accomplished"(Waltz 1967, p.108).

Related to this debate, a burgeoning international relations literature focuses on leaders as the unit of analysis, and studies more systematically the role of domestic politics in leaders' foreign policy choices in different regimes (Goemans 2000, Goemans 2008, Chiozza \& Goemans 2004, Bueno de Mesquita, Smith, Siverson \& Morrow 2003). This literature argues that leaders desire to stay in power and pick policies that maximize their chances of political survival. Domestic political preferences serve as a restraint on leaders' policy choices. As leaders care more about what their population prefers due to office prospects, they may choose policies that they would otherwise not choose in the absence of domestic constraints. 
Bueno de Mesquita et al. (2003) argue that the size of the winning coalition, the group of supporters whose support is sufficient to keep a given leader in power, has important implications for the leader's policy choices. In regimes with smaller winning coalitions, leaders are more likely to provide private goods to coalition members to stay in power, while in regimes with larger winning coalitions, it makes more sense for leaders to emphasize public goods such as national defense to garner popular support. One implication of this is that winning coalition members in democracies are less loyal, as it is not as costly to be excluded from the next winning coalition and it is more likely to be included in one after a leadership change. Because of this, democratic leaders are at greater risk of removal from office due to a lost war than are autocratic leaders. As a result, democratic leaders initiate wars only when they are relatively certain of victory. But when they get into a war, democratic leaders try harder and expend more resources to win than their autocratic counterparts do.

What does this suggest regarding the sub-optimality for the public of a given choice to initiate a conflict or not? Although Bueno de Mesquita et al. (2003) do not directly deal with the optimality of a given foreign policy choice from the population's point of view, one implication of their model is that when democracies fight, they fight harder, and they are more likely to win. Does this suggest that the decision to initiate this conflict in the first place was optimal for the public? Since that decision involves reelection concerns that do not factor into the public's utility, the answer is less clear. It is not obvious that winning a war is more optimal than avoiding it in the first place due to extra resources and effort spent by the leaders to win the war, which could rather be used to provide other private or public goods. On the other hand, if they are not as certain of the victory, democratic leaders can be very risk-averse, and might avoid wars in order not to risk their seat upon possibly losing the war, even though these wars might be preferable gambles - ignoring leaders' office concerns - for the population based on an assessment of the expected benefits versus costs. These are all conjectures, however, as although the theory predicts that democracies will prefer wars 
less frequently than autocracies and obtain better outcomes more frequently when they fight in a war, it does not produce a clear testable hypothesis on the sub-optimality of the choice to initiate a conflict or not from the voters' perspective.

The gambling for resurrection literature provides an alternative scenario for the foreign policy behavior of leaders that face bleak prospects of re-election (Downs \& Rocke 1994, Goemans \& Fey 2009). This literature argues that, when a leader has a high probability of losing office, she might be willing to gamble for resurrection, and initiate or continue a fight that her country has a low probability of winning. There is no additional cost to the leader from losing such a war, as the leader already has a low probability of political survival, but winning the war promises a better chance of retaining office. From the leader's perspective, this risky gamble is preferable, which might not be optimal for the citizens, since the leader's decision involves an external factor - re-election - that is irrelevant for the optimality of the policy choice for the population. The empirical support for this literature has been mixed (Goemans 2008). Goemans (2008) argues that the manner of exit matters a lot in leaders' incentives for gambling for resurrection, and finds that only leaders that face the risk of irregular removal from office should be willing to enter into risky conflicts to better their prospects.

Both the selectorate and the gambling for resurrection theories assume that citizens evaluate their leaders based on the outcomes their policies produce, not on the choices they make. This might be too restrictive of an assumption, especially in a salient issue like international conflict, as citizens might have preferences over the policies and strategies chosen, rather than the outcomes they produce. Recently, scholars offered another mechanism, the existence of audience costs, which does not make such an assumption. This burgeoning literature assumes that leaders suffer audience costs if they issue threats in a crisis and then fail to follow them (Fearon 1994, Smith 1998). In other words, citizens punish bluffing leaders 
even their bluffing strategies are ex ante likely to produce favorable outcomes in expectation. The implication of this is that democratic leaders avoid issuing empty threats, and when they issue a threat, they are more likely to carry it out if their opponents fail to comply. Using experiments, Tomz (2007) shows that audience costs exist, as citizens seem to dislike bluffing behavior, due to concerns about the country's reputation and arguably a normative preference for honesty.

What is the implication of this for the optimality of choices for the public? Although the existence of audience costs make democratic threats much more credible, and outcomes more favorable for democracies once their leaders issue a threat, avoiding bluffing on the other hand might produce outcomes that are not optimal for the population. Bluffing by itself can sometimes be considered a valuable strategic tool as a low cost way of achieving a country's goals in a crisis. If democratic leaders have to avoid bluffing all together in some cases for office concerns, even when this is the optimal thing to do in the absence of audience costs, this suggests that the resulting outcomes might be sub-optimal for the citizenry.

Thus, in terms of empirical testing, all the above arguments tend to anticipate a choice preference in a particular direction. The selectorate theory anticipates that democracies are extra careful in getting into wars, especially with other democracies. The gambling for resurrection arguments, on the other hand, expect more belligerent choices from leaders when they have small chances of political survival and when they face bleak prospects after removal from office. Finally, the audience cost arguments expect that democracies bluff less often, and when they do issue threats, they are more likely to carry them out. In other words, all three approaches make predictions about the relative frequencies of different strategies leaders choose in different regimes, which can be easily captured by utility estimates in an empirical model. These theories, however, do not make clear predictions regarding differences 
in leaders' likelihood of making sub-optimal choices - as defined in the previous section - in their decisions to initiate a conflict or not.

This paper offers an alternative view, which, besides taking into account these systematic differences in the crisis behavior of leaders of different regime types, incorporates deviations from optimal choices. Similar to the above theories, this approach makes the assumption that leaders ultimately care about staying in office. As the audience costs arguments, it also assumes that citizens evaluate their leaders based on policies chosen, rather than outcomes the policies might produce. One major departure from the above theories is an assumption about the level of rationality of domestic constituencies. According to this view, in making policy choices, leaders face, and are responsible to, domestic constituents that may not possess the same amount of information and cognitive capabilities to assess a foreign policy issue as the leader, and for this reason they may sometimes have biased beliefs about the optimal course of action. Furthermore, the constituents may not be aware of their limitations in calculating the optimal policy position, and they evaluate the performance of their leaders based on their own preferences, which potentially suffer from misperceptions and miscalculations. Leaders, in return, have to appease public preferences in order to avoid the risk of removal from office. For this reason, leaders' attempt to pick the best policy position might be constrained by what the public prefers regarding a given foreign policy matter. In other words, sub-optimal policy choices for the population as a whole may result from a perfectly rational behavior by leaders trying to stay in office.

This approach acknowledges that the constituents in a country may deviate from rational behavior when it comes to assessing policies and evaluating decision-makers' performances. The rationality of voters in democracies has been the subject of debate in the literature (Wittman 1995, Caplan 2007). Against the claims that voters lack the necessary information to assess policy questions accurately, that they are exposed to biased sources of information, 
and that they can be easily manipulated through biased propaganda, Wittman (1995) argues that voters are actually quite informed and that the bias in voters' expectations is exaggerated. He states that it is not costly to acquire information, and in large populations, any available bias should cancel out and optimal policy should result through the median voter's preferred position, due to "the law of large numbers". Caplan (2007) disagrees with Wittman about this "miracle of aggregation". He questions voters' rationality in democracies, and argues that in democracies voters tend to be systematically biased on policy questions. This has implications for foreign policy because professional politicians compete for the support of the public in elections. In many issue areas, he argues, biased beliefs do not cancel each other out, and the median position among the voters remains biased. ${ }^{2}$

The bias in voters' preferences - if it exists - has important implications for foreign policy decision-making, especially in democracies. The main difference between democracies and autocracies in this respect is how much the leaders care about their constituencies' preferences. If we assume that, in both autocracies and democracies, rational leaders ultimately care about staying in power, then democratic leaders must care very much about what the public prefers. In many democracies, the public can exert its influence on leaders either directly through executive elections, or indirectly through elected representatives, like the Congress in the US. Thus, foreign policy choices in democracies should adhere closely to the preferences of the public. In autocracies, however, there is not necessarily a one-to-one correspondence between the public's preferences and the leaders' choices in international politics. Even though autocratic leaders also fear removal from office, it is more costly to remove an autocratic leader from office, and it usually requires violence. For this reason, small differences between the public's expectations and the leaders' choices in foreign policy in autocracies may not result in leadership change. In other words, it may not be worth it for the public to try to forcefully remove an autocratic leader from office due to small 
or moderate differences in preferred policy positions. This extra security gives autocratic leaders more leverage in picking whatever policy they think is optimal for the country. ${ }^{3}$

The following hypothesis summarizes this approach's expectation regarding the relationship between sub-optimal foreign policy behavior tendencies of democratic versus nondemocratic leaders:

Hypothesis 1 (Constrained Optimization). Democratic leaders are more likely to make sub-optimal foreign policy choices for their population than do autocratic leaders.

Is regime type the only factor that might affect the sub-optimality of foreign policy choices? Apart from the influence of domestic politics, there might also be leader level variations in the likelihood of sub-optimal behavior. Experience is one such factor. The literature has argued that the experience of a leader can significantly affect his or her conflict behavior (Potter 2007, Horowitz, McDermott \& Stam 2005). Potter (2007), for instance, finds that the probability of a crisis involving the United States declines as the US president gains time in office. It may as well be argued that, as a leader serves in office and becomes more experienced, the quality of his or her foreign policy behavior, in particular the likelihood of choosing sub-optimal policies, will change. In particular, a more experienced leader is expected to be less likely to make sub-optimal choices. Similarly, Horowitz, McDermott \& Stam (2005), and Potter (2007) find leader age to be a significant factor affecting a state's likelihood of crisis involvement. Both studies find that older leaders are linked with higher likelihoods of crisis initiation and escalation. In a similar vein, one can expect that age has an impact on a leader's cognitive capabilities. As a leader grows older, he or she may be more prone to making sub-optimal foreign policy choices. The availability of leader-level data enables us to evaluate these expectations and control for them in the data analysis section. 


\section{Data Analysis}

To test the hypothesis derived in the previous section, this study focuses on militarized interstate disputes after World War I and investigates if regime type has an effect on leaders' likelihood of making sub-optimal choices in crisis situations. The data set used combines the Correlates of War Project's (COW) dyadic Militarized Interstate Disputes data set, ${ }^{4}$ and Goemans, Gleditsch \& Chiozza (2006)'s Archigos data set.

The main actors of the theories discussed in the previous section are national leaders in interstate crises, making policy decisions for their population; the unit of empirical analysis is therefore leader-dyad-years. Chiozza \& Goemans (2004) warn political scientists of the mismatch between theoretical and empirical units of analysis. They stress that if the theory prescribes leaders as the main actors, using country as the unit in the empirical analysis may

result in misleading inferences. A second advantage of using leaders as the unit in this study is that this choice makes possible controlling for leader-level factors such as age or experience that have been previously found to affect leaders' crisis behavior. The main difference from a country-dyad-year is that, if a country had two or more leaders in a given year, they are counted as separate observations and are potentially assigned different regressor values. ${ }^{5}$

The simple game in Figure 1(A) forms the basis for the coding of the dependent variable in the empirical analysis. The dependent variable is the outcome of a dyadic crisis situation between the leaders of two countries. There are three possible values of the outcome variable: Status Quo, showing an absence of militarized conflict between the two countries; Capitulation, meaning the target country does not respond militarily to an attack by the initiator country during a crisis; and War, indicating there is militarized conflict between the two countries. The coding of the dependent variable incorporates strategic interaction, which is an important feature of interstate crises. In the model, initiating leaders have to take into account their targets' expected response before deciding to attack or not. The three values 
of the dependent variable are coded based on the involved actors' recorded hostility levels for each directed dyadic crisis in the data set. ${ }^{6}$

The explanatory variables are measured at the leader and the country level, representing a set of domestic and international factors expected to affect crisis behavior and proneness to sub-optimal choices. Consistent with the hypothesis specified in the previous section, the main theoretical variable used in this analysis is the regime type of the countries involved. For robustness, both a binary regime type variable marking democracies and the categorical Polity score are used. The Polity score ranges from -10 to 10, -10 representing the most autocratic and 10 representing the most democratic countries (Marshall \& Jaggers 2007). At the country level, variables used to estimate preferences include relative military capabilities, major power status, alliance behavior and interest similarity, and revisionism, all of which have been theorized in the literature to affect states' crisis and conflict behavior. At the leader level, other included variables measure leaders' experience and other personal traits, which are expected to influence foreign policy behavior. The on-line appendix provides a full description of all the variables used in the analysis.

\section{Statistical Estimation}

In order to test the hypothesis from the previous section, we need a statistical technique that, first, operationalizes sub-optimal behavior, and second, enables linking independent variables, such as regime type, to the probability of making sub-optimal choices. Also, the dependent variable of the analysis represents the outcome of the strategic interaction depicted in Figure 1(A), as the initiators in the model choose their strategies based on the expected response from their target. Signorino \& Yilmaz (2003) show that, when data to be analyzed involves such strategic interaction, the failure to incorporate this into the empirical model is a major source of bias. Signorino (1999) develops a structural estimation technique 
for empirical analysis of data on strategic interaction. ${ }^{7}$ The heteroskedastic strategic probit (HSP) estimator used in this paper builds upon Signorino's strategic probit (SP) estimator to capture sub-optimal behavior tendencies of actors in a strategic interaction. ${ }^{8}$

$\mathrm{SP}$ is an appropriate technique for analyzing factors that influence actors' choices in simple strategic interactions with discrete choices. The SP model assigns regressors to actors' outcome utilities to estimate the utilities. In other words, in a model like the one in Figure 1(A), SP can estimate, for instance, a country's war expected utility, by looking at covariates such as the country's regime type, or its military capability. In a SP model, actors pick actions that give them the highest expected utility calculated based on the outcome utilities and on the expected behavior of their opponents down the game tree. In addition, the agent error version of SP allows for the possibility that actors may miscalculate their expected utilities associated with each action. According to this specification, on average, actors use the true expected utility, but in any given instance may overestimate or underestimate it and behave accordingly. These deviations from the true expected utility, represented by $\alpha_{i j}$ in Figure 1(B), are usually assumed to follow a normal distribution. SP models are based on one major assumption, that the variance of the agent error distribution is the same for each actor in each observation in the data set. In other words, according to the SP model with the agent error specification, all actors in all observations in the sample have the same likelihood of deviating from their true expected utility.

The HSP estimator I propose retains all but one of these characteristics of the SP model, while taking this technique a step further. In particular, HSP modifies the agent error specification of SP to incorporate sub-optimal choices by leaders in a conflict situation. I relax SP's assumption of homoskedasticity - common constant variance, or the equal likelihood of deviations from optimality - and allow sub-optimal behavior tendencies, measured by the variances of the $\alpha_{i j}$ parameters, to vary across different leaders depending on factors like 
domestic regime type or leader specific characteristics. ${ }^{9}$ With HSP, it is possible that one actor in a crisis is more likely to deviate from optimal behavior than another in the same or a different crisis. As in the case of SP, I assume that on average each player still picks the optimal policy (i.e. the mean of the normally distributed random deviations is still zero), but of interest is deviations from this average, in particular the variance of the deviations. If a factor increases the variance of these random deviations, this indicates that the player is more likely to deviate from the true expected utility, and choose a sub-optimal action at the end.

How are heteroskedastic agent error variance and sub-optimal foreign policy choices related? Suppose, for instance, that a leader compares Attack and Not Attack decisions, and assume that the Attack decision is the optimal choice for the population to pick in that interaction. HSP allows each leader to deviate from the true utility for the public (due to electoral concerns) in assigning expected utilities to each of these choices. The heteroskedastic error variance is the variance of these deviations from the true expected utility. As these deviations get larger, it becomes more likely that the leader will make a sub-optimal policy choice for the population. In particular, if the leader assigns a larger expected utility value to the Not Attack choice than the true utility of this action for the population, for instance, then the leader might choose to Not Attack even though the optimal choice is to Attack. These deviations from optimality are assumed to be random, representing the volatility of public opinion across different policy issues. In the homoskedastic model, the deviations are assumed to follow the same distribution for each decision, with zero mean and constant variance. In the heteroskedastic variant, on the other hand, each actor is allowed to have a different error variance. Thus, as the variance increases, it becomes more likely to experience large deviations from the correct expected utility, and hence it is increasingly more likely that a sub-optimal policy choice will be made. The important word to emphasize here is the likelihood. The larger the variance, the more likely the leader is to choose a sub-optimal 
option for the population, because a larger deviation is more likely to switch the preference ranking between Attack and Not Attack. What the estimator does, in the end, is to model this variance with regressors to find out which factors make the variance larger and hence sub-optimal choices more likely. ${ }^{10}$

\section{Results}

The main hypothesis derived in the theory section concerns the relationship between a country's regime type and its decision-makers' likelihood of making sub-optimal choices in international crises. Table 1 reports the results on the factors associated with the initiator's and target's sub-optimal choice tendencies in a crisis. In addition, the statistical model produces estimates of the factors associated with the actors' utilities from the Status Quo, War, and Capitulation outcomes of the model. Tables 2 and 3 report these outcome utility estimates for the initiator and the target leader. Outcome utilities determine what is optimal for an actor to choose in a crisis situation, while variations in sub-optimal behavior tendency suggest how likely the actor is to deviate from an optimal solution in a given crisis. In other words, auxiliary results presented in Tables 2 and 3 indicate what factors make various outcomes more or less attractive to leaders in a crisis, while Table 1 focuses on the main argument of this paper and shows what factors make a leader more likely to deviate from a more attractive to a less attractive choice.

For both the initiator and the target, five different models are reported in Table 1. They employ alternative specifications for proneness to sub-optimal choices, and include different operationalizations of regime type. Model 1 includes the Polity score of the countries involved (Democracy); the changes in the Polity score from the previous year $(\triangle$ Democracy); a dummy variable marking major powers (Major Power); and leader's age (Age) and tenure $(\log ($ Tenure $))$ to control for experience as a potential factor affecting the likelihood of sub- 
optimal choices. Model 2 replaces Democracy with a binary variable that takes the value of 1 when Democracy is greater than or equal to 6. Model 3 is a reduced form version that only includes state level variables, excluding the leader-level variables $\log ($ Tenure) and Age. Models 4 and 5 include Democracy ${ }^{2}$ as a regressor in two different specifications to test if there are nonlinearities in the effect of democracy on the likelihood of making sub-optimal choices in international crises.

As can be seen from Tables 2 and 3, Models 1 through 5 also utilize different regressors to estimate outcome utilities. The five specifications include in the utilities a subset of Relative Cap., Revisionist, Both Democ., Democracy, $\triangle$ Democracy, Defense Pact, S Score, $\log$ (Distance), Election, and Prev.times. ${ }^{11}$ All these variables, representing systemic, state and leader level factors, are theoretically motivated and are widely used control variables in empirical studies of international conflict. First, Relative Cap., relative military capabilities between the two states, has been employed in many empirical models of international conflict, due to the important role it plays in realist and rational choice theories (Powell 1999, Rousseau, Gelpi, Reiter \& Huth 1996, Bennett \& Stam 1996, Bennett \& Stam 2000a). By including this variable in both players' War utilities, I test the hypothesis that, as a state gets relatively stronger against its opponent, it will be more likely to use force in a dispute. Realist theoretical approaches to international conflict also argue that shared security interests play an important role in states' crisis behavior. Joint alliance membership is a variable that has been widely used in modeling international conflict (Bueno de Mesquita 1981, Bremer 1992). A defense pact is the strongest type of alliance commitment coded in the Correlates of War data. Defense Pact is included in the Status Quo utility of the initiator to test if this type of alliance commitment reduces the likelihood of conflict initiation between two states. Similarly, alliance portfolio similarity plays an important role in the expected utility theory of war in predicting international conflict (Bueno de Mesquita 1981, Bennett \& Stam 2000a, Bennett \& Rupert 2003). Signorino \& 
Ritter (1999) offer S Score as a theoretically superior approach to measuring the similarity of two countries' alliance commitments (Signorino \& Ritter 1999). Accordingly, I include $S$ Score in the initiator's Status Quo utility to control for the potentially pacifying effect in a dispute of the similarity of alliance portfolios between the two states. Revisionist is a proxy for a given state's satisfaction with the status quo in a given crisis. It is included in the two states' War utilities to control for states that have a stronger preference for using violence to change the status quo in a given interaction (Rousseau et al. 1996). Regime type is argued to be an important determinant of conflict behavior (Fearon 1994, Bueno de Mesquita, Morrow, Siverson \& Smith 1999, Schultz 1999). Both Democ., an indicator variable that marks if both states in the dyad are democratic, is included in the Initiator's Status Quo utility to test the argument that two democracies are less likely to fight with each other, as proposed by the democratic peace theory. If this argument holds, Both Democ. should make Status Quo more attractive to the initiating leader. I also included Democracy variable to both states' War payoffs to control for any unilateral effect of regime type on states' conflict behavior (Huth \& Allee 2002). Similarly, the $\triangle$ Democracy variable controls for a potentially different conflict propensity of democratizing states (Mansfield \& Snyder 1995, Ward \& Gleditsch 1998, Mansfield \& Snyder 2002, Narang \& Nelson 2009). log(Distance), the physical distance between states, is included in the Initiator's Status Quo utility to control for the effect of geographical proximity on the likelihood of conflict initiation. It has been argued that geographical proximity makes conflicts of interest more likely between states, and military conflicts more feasible if such conflicts of interest exist (Bremer 1992). Finally, at the leader level, two variables are included in both players' War utilities: the Election variable aims to control for diversionary incentives of leaders in initiating conflict during election years to take advantage of a potential "rally around the flag" effect (Levy 1989, Chiozza \& Goemans 2003). Prev. times, or the number of times a leader has previously been in office, 
is another proxy for leaders' experience, which has been argued to affect the likelihood of conflict involvement (Potter 2007, Horowitz, McDermott \& Stam 2005).

\section{Are Democratic Leaders More Prone to Making Sub-optimal Choices?}

Regarding the effect of Democracy on the likelihood of sub-optimal choice in international crises, the constrained optimization approach reflected in Hypothesis 1 anticipates a significant positive coefficient, as it is argued that democratic foreign policy is more likely to represent public's potentially sub-optimal preferences. The empirical results show robust support for this hypothesis. Table 1 reports the results on the magnitude of variations in sub-optimal choices in international crises. A positive coefficient on a variable means that, other things being equal, the variable increases the likelihood of deviations from optimal behavior for that actor. In contrast, a negative coefficient indicates that, when that covariate increases, sub-optimal behavior will be less likely. In all five specifications presented, democracy is a factor that significantly increases the likelihood of deviations from optimal behavior. This is true for the leaders of both democratic initiators and democratic targets. ${ }^{12}$ As the table shows, these results are robust to alternative specifications for deviations from optimality and for outcome utilities, and the effect remains significant when different operationalizations of democracy are used. ${ }^{13}$

Democratization is also argued to be an important factor in foreign policy behavior (Mansfield \& Snyder 1995, Ward \& Gleditsch 1998). Even though there is a renewed interest in this topic and a recent empirical disagreement on the effect of democratization on conflict (Narang \& Nelson 2009), the existing literature does not discuss the effect of democratization on the sub-optimality of foreign policy choices. The statistical analysis that is presented here suggests that democratization has an important influence on the likelihood of sub-optimal choices in international politics. In Models 1,2 , and 5 , for the initiator, $\triangle$ Democracy has a 
positive significant coefficient, indicating that a faster pace of democratization increases the levels of sub-optimal behavior in international crises. For the target leader, $\triangle$ Democracy does not have a significant coefficient. For a democratic leader who considers initiating an international crisis, then, improvements in the country's democratic governance over the past year increase the likelihood of a sub-optimal decision. This effect operates through both an increased democracy score and the democratization variable in the model.

What is the size of democracy's effect on the likelihood of sub-optimal behavior? For an intuitive interpretation of the estimation results, I calculate the percentage increase in the variance parameter in response to a change in the Democracy variable. For instance, results from Model 1 for the conflict initiator show that changing Democracy from -10 to 10, the whole range of the variable, increases the variance parameter measuring the likelihood and potential magnitude of deviations from optimality by $32 \%$. There is a similar pattern in the other four specifications: on average, democracies have $20 \%$ to $43 \%$ larger variance parameters compared to autocracies in all five models reported. This estimate does not take into account the change in $\triangle$ Democracy variable. If we assume that this hypothetical transition from a complete autocracy to a complete democracy takes place in one year, we also need to take into account the change in the $\triangle$ Democracy variable in calculating the change in the variance parameter. When we do that, the substantive effect of democracy on the likelihood of sub-optimal choices is larger in magnitude: this newly democratized country will on average experience a $105 \%$ to $207 \%$ increase in its tendency to deviate from optimality according to the five models reported. This implies that the error variance more than doubles in response to complete democratization in a single year. The effect is still sizeable for less extreme changes in the polity score. For instance, a 5-point democratization in a given year (a two standard deviations change in the sample) increases the sub-optimality probability by about $20 \%$. For the target leader, the effect is even more pronounced: in any 
of the five models estimated for the target leader, increasing the Democracy variable's value from -10 to 10 more than doubles the player's error variance.

Even though democracy has a significant effect in the same direction on both the initiating and target leaders' sub-optimal choice tendencies, significant differences remain between the two types of leaders. First, although democratization significantly increases initiating leaders' likelihood of making sub-optimal choices, the effect is not distinguishable from zero for target leaders. Perhaps most strikingly, the major power status of a country has opposite significant effects on its leader's tendency to pick sub-optimal policies in conflict initiation and resistance decisions. The results suggest that leaders of major power initiators are more likely to make sub-optimal choices in an international crisis. This is not true when the major power leader is a target, however. When a major power country is attacked, its leader is significantly less likely to make a sub-optimal choice compared to the leaders of less powerful countries. In any of the five specifications considered, when leaders of major power countries initiate a crisis, their estimated variance is on average $23-25 \%$ larger than that of less powerful countries. On the other hand, when they are targeted, major power leaders are significantly less likely to deviate from optimal behavior, represented by an estimated variance parameter that is on average $41 \%$ to $56 \%$ smaller than that of the leaders of less powerful countries. This is a very interesting finding, yet the theories discussed in the previous section do not guide us on this difference in behavior between the leaders of initiating versus target major powers. Why do major power leaders are less likely to make sub-optimal choices when they are attacked? One potential theoretical explanation is that Major Power serves as a proxy for the diversity of a state's interests. It is possible that major powers like the US have more diverse strategic interests in different parts of the world, and this might be partially responsible for the larger estimated error variance for the initiators. For the targets, on the other hand, in many specifications, Major Power has a significant coefficient in the opposite 
direction, perhaps because the decisions to resist or not are only conditional on an initial attack, which reduces the diversity of the target's interests for that crisis.

To further test the potential link between the diversity of interests and the size of the estimated agent error variances, we can look at strategic rivalries between states. It is possible that for states who are in a rivalry, much of the foreign policy is focused on the opponent, which reduces the diversity of the state's interests. This might in turn result in a smaller estimated error variance. To control for this possibility, I re-estimated the five models discussed above, with Strategic Rivalry added to the variance and Initiator's War utilities. ${ }^{14}$ Surprisingly, this variable in the variance specification has a positive and significant coefficient for initiators, and an insignificant coefficient for targets. The implication is that, if the dyad is in a strategic rivalry, initiator leaders are more likely to deviate from optimal choices, while this effect in the same direction is insignificant for target leaders. On the other hand, the coefficient of Strategic Rivalry in Initiator's War utility is positive, and significant in two specifications, which suggests that a leader is more likely to initiate a militarized crisis against a state if the two states are in a rivalry. The results establish the robustness of the original findings on the relationship between regime type and the error variance. None of the substantive results on the error variance changes when we add this variable to the specification, except Age becoming insignificant in Initiator's utility. In particular, the statistical and substantive effect of Democracy stays the same in all five specifications reported.

To summarize, with the help of data, I have shown that regime type, major power status, age and experience have an effect on leaders' tendency to make sub-optimal choices in international crises. Can these results indicate whether a given conflict initiation or the decision to resist an attack was a sub-optimal choice for a country? In addition to capturing leaders' proneness to making sub-optimal choices, the statistical estimation results enable us to make probabilistic statements about whether a particular outcome, or a choice by an actor, 
was sub-optimal or not. The model can estimate the expected utility difference between the actions available to each player, and also the variance of the deviations from optimality. Using these two estimates, one can calculate the probability of getting a deviation from optimal behavior that is large enough to switch the sign of the expected utility difference and change the estimated preferred action for a player. ${ }^{15}$ Figure 2 shows the distribution of these probabilities for all the leaders in the sample. As the left plot in Figure 2 demonstrates, most of the decisions about conflict initiation are unlikely to involve sub-optimal choices, as the probability of getting a large enough deviation to switch the initiator's preferences is close to zero for most of the cases. The average probability that an observation involves a sub-optimal choice by the initiator is around .06 in all five specifications reported. Still, some of the observations are highly likely to involve a sub-optimal choice as the large standard deviation of the estimated probabilities indicates. More strikingly, the targets' decision to resist against an attack or not is more likely to involve a sub-optimal choice. The plot on the right in Figure 2 shows the distribution of the sub-optimality probabilities for the target countries in the sample. Given that a country faces a military attack, its leader on average has about a .36 probability of making a sub-optimal choice in her response.

As a measure of the model's predictive performance, I calculate the model's outcome prediction for each observation in the sample. All the five model specifications presented in Tables 1-3 have a very good predictive capacity. These specifications correctly predict on average about $84 \%$ of the outcomes in the sample, beating the modal category of $77 \%$. In addition, likelihood ratio tests suggest that each of the five HSP models fits significantly better than the homoskedastic variants, with comparison p-values well below $.0001 .{ }^{16}$ This suggests that modeling heteroskedasticity in this context is not only substantively interesting, but is statistically necessary as well. ${ }^{17}$ To further illustrate the model's predictive capability, I discuss one example case from the sample, the Iran Hostage Crisis of $1980 .^{18}$ 
Iran Hostage Crisis. Perhaps one of the first cases that come to mind in recent history when talking about sub-optimal policy choices in international crises is the failed rescue operation during the Iran Hostage Crisis. ${ }^{19}$ The Hostage Crisis started when, during the Iranian revolution, Iranian students took control of the US Embassy in Tehran and took 66 Americans hostage in November 1979. The US president Jimmy Carter's early reaction to the situation was to use diplomatic means exclusively and avoid the use of military force. However, after the crisis lingered for months and the US officials could not successfully negotiate a release of the hostages, President Carter ordered a very risky military rescue operation in April 1980, code-named Operation Eagle Claw, which failed to achieve the release of the hostages and resulted in the death of 8 Americans. The crisis ended and the hostages were finally released after 444 days, months after the failed operation, in January 1981. My model predicts that Carter's decision to launch this risky military operation had a sub-optimal choice probability of .37 , one of the larger probabilities in the sample.

The rescue mission was the greatest disaster of Carter's presidency (Houghton 2001). It was deemed by many authorities, including people from the Carter administration, to have a low probability of success, with almost guaranteed loss of life. Scholars proposed a variety of theories explaining the choice and the timing of this policy. ${ }^{20}$ The theory proposed in this paper offers another alternative story that complements the existing ones and adds to our understanding of the rescue mission by positing that sub-optimal public preferences for a tougher policy and the public pressure on President Carter might have played a role in Carter's choice. As each day passed without the release of the hostages, the public pressure increased on Carter to bring the crisis to an end and the hostages back home. Media also played a significant role in building the immense pressure on Carter. Walter Croncite of CBS would close his report every night during the crisis by reporting the number of days the Americans had been held by Iranians (Houghton 2001). McDermott (1998) and Gartner (1993) provide a very clear account of the public sentiments towards President Carter and the 
US foreign policy during those days. It appears that, although at the crisis onset President Carter enjoyed a rally-around-the-flag boost in his popular support, as the crisis dragged, his approval ratings steadily dropped, and they plummeted right before the rescue mission. More and more citizens thought that Carter's peaceful foreign policy choices in dealing with the crisis were a failure. An ABC-Harris poll showed that right before the operation, only $12 \%$ of the population supported Carter's peaceful means to deal with the hostage crisis (Farber 2005, McDermott 1998). Facing the decline in his popular support and the demands for tougher policies, together with the pressure of an upcoming election against a challenger Reagan who steadily increased his support base as the crisis dragged, Carter had to choose to launch the risky rescue operation.

The Secretary of State of the time, Cyrus Vance, thought that negotiations should have been given more time, and it was better to wait for the Iranian political environment to settle than to launch a military rescue operation that was highly likely to fail. In McDermott (1998)'s words, "Ex post facto, an analyst can see that the best option had been offered by Secretary Vance. The hostages were released essentially unharmed by the Iranians when they no longer served any function. Once the revolutionary government was secure, the hostages were allowed to leave,.... In some sense, Carter received the right advice - to do nothing from Vance; he chose to ignore it, however, and take the more risky military option."

\section{Conclusion}

An old debate in political science questions the relationship between regime type and the quality of foreign policy. While some argued that democratic foreign policy is more likely to be sub-optimal, as democratic leaders face difficulties in the implementation of foreign policy due to domestic constraints, others argued that democratic politics facilitates a healthy for- 
eign policy. Surprisingly, there had not been any empirical study in the literature comparing these opposing claims. Part of the reason was that there was no clear way of operationalizing and objectively measuring sub-optimality in foreign policy.

This study fills the gap in the literature by providing an analysis of the link between a country's regime type and its leader's tendency to choose sub-optimal policies in international crises. The statistical tools I developed and used in this paper help estimate decision-makers' tendency to deviate from optimal policies for their countries during international crises. Statistical analysis of international disputes during the period after World War I shows that democratic leaders are more prone to making foreign policy choices that are sub-optimal for their country than do autocratic leaders. This result is robust to different operationalizations of democracy and democratization. The findings in this paper may not put an end to this old debate on the link between regime type and foreign policy optimality, but hopefully they will facilitate a healthier discussion where opposing claims can be tested and rejected. 


\section{Notes}

${ }^{1}$ Note that this definition does not rule out the possibility that choices that are sub-optimal for the state might be perfectly optimal for the leaders. In fact, one of the mechanisms discussed in the next section incorporates this possibility.

${ }^{2}$ His empirical examples include the tendency among the public to underestimate the benefits of free market mechanism and the benefits of interactions with foreigners.

${ }^{3}$ One might argue that leaders often have the ability to control and shape the public opinion. As long as there exists some degree of independence of the public opinion from leader preferences, the implications of this theory will hold. Secondly, as long as leaders have a better estimate of the optimal policy than the public does, and they can monitor the public's preferences accurately enough, the assumption of perfectly rational leaders is not crucial.

${ }^{4}$ The MIDs data set is generated using the EUGene software. For more information, see Ghosn \& Bennett (2003) and Bennett \& Stam (2000b).

${ }^{5}$ Dyads between all contemporaneous leaders from 1919 to 1999 - whether they are involved in a conflict or not - create a very large data matrix. More than $99 \%$ of these observations are peaceful dyads. Analyzing such a big sample is not only cumbersome and computationally costly; it is also unnecessary. As King \& Zeng (2001b) show, most of the information in such unbalanced samples is in the rare observations rather than abundant non-events. For these reasons, the analyses in this section are conducted in a smaller sample generated through choice-based sampling. This method endogenously samples based on the values of the dependent variable by retaining all conflict observations and using only a random sub-sample of peace dyads. The merits of this sampling method in international relations empirical research, where many interesting dependent variables are rare events, are discussed in detail in the literature (King \& Zeng 2001a).

${ }^{6}$ There are six hostility levels in the data set: $0=$ No hostility, $1=$ No militarized action, $2=$ Threat to use force, $3=$ Display of force, $4=$ Use of Force, $5=$ War. A country is coded to use force (attack for the initiator, resist for the target) if it reached a hostility level of 4 or higher in that crisis. MIDs data set's dispute originator indicator is used to code the sequentiality of the dependent variable. For non-dispute cases, both directed dyads are included in the data set and choice-based sampling procedure described above randomly selected among the two to possibly include one into the sample. The substantive results about the link 
between regime type and the levels of uncertainty are the same if the analyses are conducted on a restricted sample of disputes (above hostility level 1). These additional results are likely to suffer from selection bias, but they are available from the author upon request.

${ }^{7}$ For a simpler alternative to this estimator, see Bas, Signorino \& Walker (2008).

${ }^{8} \mathrm{HSP}$ estimator is discussed in detail in Bas (2011). A description appears in the online appendix to this paper.

${ }^{9}$ This approach of linking actors' sub-optimal choice tendencies to regressors is similar to heteroskedastic probit models where error variance is modeled with regressors. Examples in the conflict literature include Clark \& Nordstrom (2005) and Clark, Nordstrom \& Reed (2008).

${ }^{10}$ Thus, a larger variance does not necessarily indicate sub-optimality in a specific crisis. It is possible that a leader with a larger estimated variance in a given crisis chooses the optimal policy, while a leader with a smaller variance in another crisis chooses a sub-optimal policy, because deviations from optimality are random. The difference is that, on average, the leader who experiences a larger variance will be more likely to make sub-optimal choices compared to the other leader, because a large enough deviation from optimality is more probable from a distribution with a larger variance than one with a smaller variance.

${ }^{11}$ The variable descriptions are presented in the Appendix.

${ }^{12}$ These results by no means suggest that democratic leaders are more belligerent in international crises. As the auxiliary results presented in Tables 2 and 3 show, both Democracy and $\triangle$ Democracy negatively affect a leader's utility from initiating a conflict. This means that democratic leaders are less likely to initiate crises in general, and they prefer not to get into a conflict with a fellow democracy in particular. This is in line with the vast literature on the democratic peace. One caveat to this finding is that, when they are attacked, democracies are more likely to resist. The negative coefficient of $\triangle$ Democracy also contrasts Mansfield and Snyder's (1995)'s findings, which are recently challenged by Narang \& Nelson (2009).

${ }^{13}$ Although not reported here, results are also robust to a variety of other checks, including: using Executive Constraints index from the Polity data set instead of the Polity score; lagging the regime type variables; controlling for states that have a Polity score that lies between -5 and 5 ; restricting the analysis to different time periods in the data set, such as excluding World War II years, or only looking at the Cold War years; including a variable in the variance specifications measuring each leader's manner of entry to office; and using 
different operationalizations for alliance, experience, and military capabilities variables used in the analysis. These results are available upon request.

${ }^{14}$ These results are reported in the online appendix.

${ }^{15}$ In the extreme case, the probability of getting a shock that would make the player choose another action would be .5 , because that is the highest possible probability of getting a positive (negative) draw from a normal distribution with mean zero when the estimated utility difference is negative (positive).

${ }^{16}$ Results are presented in the online appendix.

${ }^{17}$ In a working paper, Keele \& Park (2006) argue that, due to potential fragility of the heteroskedastic probit model, scholars should at a minimum use different starting values. I re-estimated the reported models in the manuscript with 100 different random starting values and I reached the same estimates. Keele \& Park (2006) also suggest plotting the profile likelihood function for various coefficient values to check for any flat regions, which might indicate poor convergence. My examination of the profile likelihood graphs indicates that the coefficient estimates are stable and converged successfully.

${ }^{18}$ The on-line appendix contains a table with several more example crises from the data set with the involved leaders' estimated probabilities of sub-optimal choices. These examples include conflicts between an old colonial power and its ex-colony over the control of a strategic territory, which was ultimately resolved in favor of the ex-colony after military conflict and international pressure (Bizerte Crisis, Suez Canal Crisis, Ifni War); a costly, unnecessary or unsuccessful rescue attempt in response to a hostage crisis (Mayaguez Incident and the Iran Hostage Crisis); and conflicting sovereignty claims of two neighboring countries over an insignificant piece of territory, which escalated into costly violence and required major power intervention (Imia-Kardak). In most of these cases, there is a scholarly consensus that one or more of the involved parties' choices were sub-optimal, which seems to be confirmed by the sub-optimality probability estimates of the model.

${ }^{19}$ For a detailed account of the hostage crisis and the Iran-US relations during the period, see Sick (1986).

${ }^{20}$ See Houghton (2001) for a summary of the alternative explanations. 


\section{References}

Bas, Muhammet A. 2011. "Measuring Uncertainty in International Relations: Heteroskedastic Strategic Models." Working Paper, Department of Government, Harvard University.

Bas, Muhammet A., Curtis S. Signorino \& Robert W. Walker. 2008. "Statistical Backwards Induction: A Simple Method for Estimating Recursive Strategic Models." Political Analysis 16(1):21-40.

Bennett, D. Scott \& Allan C. Stam. 1996. "The Duration of Interstate Wars, 1816, 1985." American Political Science Review 90:239-257.

Bennett, D. Scott \& Allan C. Stam. 2000a. "A Universal Test of an Expected Utility Theory of War." International Studies Quarterly 44:451-480.

Bennett, Scott D. \& Allan Stam. 2000b. "EUGene: A Conceptual Manual." International Interactions 26:179-204.

Bennett, Scott \& Matthew C. Rupert. 2003. "Comparing Measures of Political Similarity: An Empirical Comparison of S Versus Tau-B in the Study of International Conflict." Journal of Conflict Resolution 47:367.

Bremer, Stuart A. 1992. "Dangerous Dyads: Conditions Affecting the Likelihood of Interstate War, 1816-1965." Journal of Conflict Resolution 36:309.

Bueno de Mesquita, Bruce. 1981. The War Trap. New Haven: Yale University Press.

Bueno de Mesquita, Bruce, Alastair Smith, Randolph M. Siverson \& James D. Morrow. 2003. The Logic of Political Survival. Cambridge, MA: MIT Press. 
Bueno de Mesquita, Bruce, James Morrow, Randolph Siverson \& Alastair Smith. 1999. "An Institutional Explanation of the Democratic Peace." American Political Science Review 93(4):791-808.

Caplan, Bryan. 2007. The Myth of Rational Voter. Princeton, NJ: Princeton University Press.

Chiozza, Giacomo \& Henk Goemans. 2003. "Peace Through Insecurity: Tenure and International Conflict." The Journal of political Economy 47:443-467.

Chiozza, Giacomo \& Henk Goemans. 2004. "International Conflict and the Tenure of Leaders: Is War Still Ex Post Inefficient?" American Journal of Political Science 48:604-619.

Clark, David \& Timothy Nordstrom. 2005. "Democratic Variants and Domestic Variance: How Domestic Constraints Shape Interstate Conflict." The Journal of Politics 67:25070.

Clark, David, Timothy Nordstrom \& William Reed. 2008. "Substitution Is in the Variance: Resources and Foreign Policy Choice." American Journal of Political Science 52:763-73.

de Tocqueville, Alexis. 1988. Democracy in America. New York: Harper Perennial.

Downs, George W. \& David M. Rocke. 1994. "Conflict, Agency, and Gambling for Resurrection: The Principal-Agent Problem Goes to War." American Journal of Political Science 38:362-80.

Farber, David. 2005. Taken Hostage: The Iran Hostage Crisis and America's First Encounter with Radical Islam. Princeton, NJ: Princeton University Press.

Fearon, James D. 1994. "Domestic Political Audiences and the Escalation of International Crises." American Political Science Review 88(3):577-92. 
Gartner, Scott. 1993. "Predicting the timing of carter's decision to initiate a hostage rescue attempt: Modeling a dynamic information environment." International Interactions 18:365-86.

Gartzke, Erik \& Kristian S. Gleditsch. 2004. "Why Democracies May Actually Be Less Reliable Allies." American Journal of Political Science 48:775-795.

Ghosn, Faten \& Scott Bennett. 2003. "Codebook for the Dyadic Militarized Interstate Dispute Data, Version 3.10.".

Goemans, Hein. 2000. War and Punishment: The Causes of War Termination and the First World War. Princeton, NJ: Princeton University Press.

Goemans, Hein. 2008. "Which Way Out? The Manner and Consequences of Losing Office." Journal of Conflict Resolution 53:771-94.

Goemans, Hein \& Mark Fey. 2009. "Risky but Rational: War as an Institutionally Induced Gamble." Journal of Politics 71:35-54.

Goemans, Henk, Kristian Skrede Gleditsch \& Giacomo Chiozza. 2006. "Archigos. A Data Base on Leaders 1875 - 2004.".

Hamilton, Alexander, James Madison \& John Jay. 1961. Federalist No. 70: The Executive Department Further Considered. In The Federalist Papers, ed. Clinton Rossiter. New York: New American Library.

Horowitz, Michael C., Rose McDermott \& Allan C. Stam. 2005. "Leader Age, Regime Type, and Violent International Relations." Journal of Conflict Resolution 49:661-85.

Houghton, David P. 2001. US Foreign Policy and the Iran Hostage Crisis. New York, NY: Cambridge University Press. 
Huth, Paul \& Todd Allee. 2002. "Domestic Political Accountability and the Escalation and Settlement of International Disputes." Journal of Conflict Resolution 46:754-790.

Keele, Luke J. \& David K. Park. 2006. "Ambivalent about Ambivalence: A Re-Examination of Heteroskedastic Probit Models." Working Paper.

Kennan, George. 1950. American Diplomacy. Chicago: The University of Chicago Press.

King, Gary \& Langche Zeng. 2001a. "Explaining Rare Events in International Relations." International Organization 55:693-715.

King, Gary \& Langche Zeng. 2001b. "Logistic Regression in Rare Events Data." Political Analysis 9:137-163.

Levy, Jack S. 1989. The Diversionary Theory of War: A Critique. In Handbook of War Studies, ed. Manus I. Midlarsky. Ann Arbor, MI: University of Michigan Press.

Mansfield, Edward \& Jack Snyder. 1995. "Democratization and the Danger of War." International Security 20(1).

Mansfield, Edward \& Jack Snyder. 2002. "Democratic Transitions, Institutional Strength, and War." International Organization 56(2).

Marshall, Monty G. \& Keith Jaggers. 2007. "Polity IV Project: Political Regime Characteristics and Transitions, 1800-2006.".

McDermott, Rose. 1998. Risk-Taking in International Politics: Prospect Theory in American Foreign Policy. Ann Arbor: The University of Michigan Press.

Narang, Vipin \& Rebecca Nelson. 2009. "Who Are These Belligerent Democratizers? Reassessing the Impact of Democratization on War." International Organization 63:35779. 
Potter, Phillip B. K. 2007. "Does Experience Matter? American Presidential Experience, Age, and International Conflict." Journal of Conflict Resolution 51:351-378.

Powell, Robert. 1999. In the Shadow of Power. Princeton, NJ: Princeton University Press.

Rousseau, David, Christopher Gelpi, Dan Reiter \& Paul K. Huth. 1996. "Assessing the Dyadic Nature of the Democratic Peace, 1918-88." American Political Science Review 90(3):512-533.

Schultz, Kenneth. 1999. "Do Domestic Institutions Constrain or Inform?: Contrasting Two Institutional Perspectives on Democracy and War." International Organization 53(3):233-266.

Sick, Gary. 1986. All Fall Down: America's Tragic Encounter with Iran. New York: Penguin Books.

Signorino, Curtis S. 1999. "Strategic Interaction and the Statistical Analysis of International Conflict." American Political Science Review 93(2):279-97.

Signorino, Curtis S. \& Jeffrey M. Ritter. 1999. "Tau-b or Not Tau-b: Measuring the Similarity of Foreign Policy Positions." International Studies Quarterly 43:115-144.

Signorino, Curtis S. \& Kuzey Yilmaz. 2003. "Strategic Misspecification in Regression Models." American Journal of Political Science 47(3):551-66.

Smith, Alastair. 1998. "International Crises and Domestic Politics." American Political Science Review 92(3):577-92.

Tomz, Michael. 2007. "Domestic Audience Costs in International Relations: An Experimental Approach." International Organization 61:821-40. 
Tuchman, Barbara. 1984. The March of Folly: from Troy to Vietnam. New York, NY: Ballantine Books.

Waltz, Kenneth. 1967. Foreign Policy and Democratic Politics: The American and British Experience. Boston: Little, Brown and Company.

Ward, Michael \& Kristian Gleditsch. 1998. "Democratizing for Peace." American Political Science Review 92(1):51-61.

Wittman, Donald. 1995. The Myth of Democratic Failure. Chicago, IL: The University of Chicago Press. 


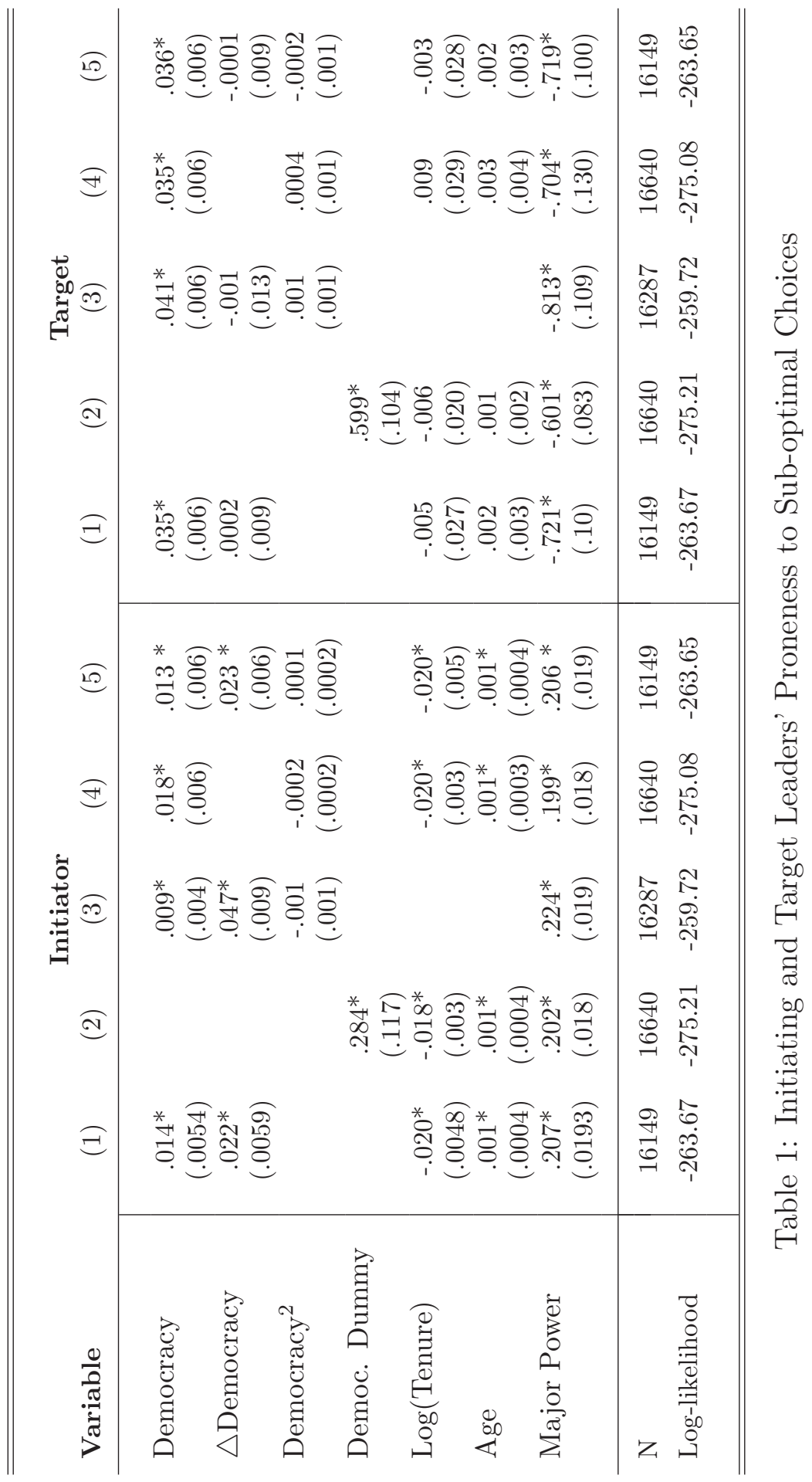




\begin{tabular}{|c|c|c|c|c|c|}
\hline Variable & (1) & $(2)$ & $(3)$ & (4) & (5) \\
\hline \multicolumn{6}{|l|}{ Status Quo } \\
\hline Defense pact & $\begin{array}{l}.154 \\
(.258)\end{array}$ & $\begin{array}{c}.262 \\
(.321)\end{array}$ & $\begin{array}{l}-.006 \\
(.219)\end{array}$ & $\begin{array}{l}.303 \\
(.291)\end{array}$ & $\begin{array}{c}.155 \\
(.259)\end{array}$ \\
\hline S Score & $\begin{array}{l}.032 \\
(.097)\end{array}$ & $\begin{array}{l}-.036 \\
(.096)\end{array}$ & $\begin{array}{c}.031 \\
(.118)\end{array}$ & $\begin{array}{c}.010 \\
(.090)\end{array}$ & $\begin{array}{c}.021 \\
(.098)\end{array}$ \\
\hline $\log ($ Distance $)$ & $\begin{array}{l}.040 \\
(.027)\end{array}$ & $\begin{array}{l}.014 \\
(.024)\end{array}$ & $\begin{array}{c}.022 \\
(.027)\end{array}$ & $\begin{array}{l}.054^{*} \\
(.025)\end{array}$ & $\begin{array}{l}.040 \\
(.028)\end{array}$ \\
\hline Both Democ. & $\begin{array}{l}.564^{*} \\
(.163)\end{array}$ & $\begin{array}{l}.645^{*} \\
(.167)\end{array}$ & $\begin{array}{l}.603^{*} \\
(.209)\end{array}$ & $\begin{array}{l}.512^{*} \\
(.145)\end{array}$ & $\begin{array}{l}.581^{*} \\
(.160)\end{array}$ \\
\hline \multicolumn{6}{|l|}{ Capitulation } \\
\hline Constant & $\begin{array}{l}-9.93^{*} \\
(.666)\end{array}$ & $\begin{array}{c}-11.52^{*} \\
(.715)\end{array}$ & $\begin{array}{c}-10.54^{*} \\
(.68)\end{array}$ & $\begin{array}{l}-9.72 * \\
(.735)\end{array}$ & $\begin{array}{c}-9.99^{*} \\
(.659)\end{array}$ \\
\hline \multicolumn{6}{|l|}{ War } \\
\hline Election & $\begin{array}{c}.057 \\
(.145)\end{array}$ & $\begin{array}{c}.075 \\
(.138)\end{array}$ & $\begin{array}{l}-.066 \\
(.161)\end{array}$ & $\begin{array}{c}.106 \\
(.131)\end{array}$ & $\begin{array}{c}.059 \\
(.147)\end{array}$ \\
\hline Democracy & $\begin{array}{c}-.116^{*} \\
(.034)\end{array}$ & & $\begin{array}{c}-.080^{*} \\
(.035)\end{array}$ & $\begin{array}{c}-.128^{*} \\
(.040)\end{array}$ & $\begin{array}{l}-.115^{*} \\
(.035)\end{array}$ \\
\hline$\triangle$ Democracy & & & $\begin{array}{c}-.289^{*} \\
(.047)\end{array}$ & & \\
\hline Democ. Dummy & & $\begin{array}{c}-2.20^{*} \\
(.906)\end{array}$ & & & \\
\hline Prev. times & $\begin{array}{l}.18^{*} \\
(.043)\end{array}$ & $\begin{array}{l}.138^{*} \\
(.045)\end{array}$ & & $\begin{array}{l}.140^{*} \\
(.041)\end{array}$ & $\begin{array}{l}.181^{*} \\
(.044)\end{array}$ \\
\hline Revisionist & $\begin{array}{l}8.63^{*} \\
(.702)\end{array}$ & $\begin{array}{l}9.19^{*} \\
(.502)\end{array}$ & $\begin{array}{c}10.03^{*} \\
(.537)\end{array}$ & $\begin{array}{l}8.23^{*} \\
(.444)\end{array}$ & $\begin{array}{l}8.66^{*} \\
(.721)\end{array}$ \\
\hline Relative Cap. & $\begin{array}{l}2.29^{*} \\
(.531)\end{array}$ & $\begin{array}{l}2.54^{*} \\
(.496)\end{array}$ & $\begin{array}{l}2.16^{*} \\
(.601)\end{array}$ & $\begin{array}{l}2.22^{*} \\
(.468)\end{array}$ & $\begin{array}{l}2.28^{*} \\
(.552)\end{array}$ \\
\hline $\mathrm{N}$ & 16149 & 16640 & 16287 & 16640 & 16149 \\
\hline Log-likelihood & -263.67 & -275.21 & -259.72 & -275.08 & -263.65 \\
\hline
\end{tabular}

Table 2: Initiator's Outcome Utilities 


\begin{tabular}{lccccc}
\hline \hline Variable & $(1)$ & $(2)$ & $(3)$ & $(4)$ & $(5)$ \\
\hline War & & & & & \\
\hline Democracy & $.007^{*}$ & & $.005^{*}$ & $.009^{*}$ & $.007^{*}$ \\
& $(.002)$ & & $(.002)$ & $(.003)$ & $(.003)$ \\
$\triangle$ Democracy & & & -.001 & & \\
& & & $(.004)$ & & \\
Democ. Dummy & & $.258^{*}$ & & & \\
& & $(.079)$ & & & \\
Election & $.042^{*}$ & $.054^{*}$ & $.046^{*}$ & $.059^{*}$ & $.042^{*}$ \\
& $(.020)$ & $(.020)$ & $(.013)$ & $(.029)$ & $(.020)$ \\
Prev. times & $.039^{*}$ & $.040^{*}$ & & $.040^{*}$ & $.039^{*}$ \\
& $(.015)$ & $(.013)$ & & $(.017)$ & $(.015)$ \\
Relative Cap. & $.387^{*}$ & $.485^{*}$ & $.318^{*}$ & $.430^{*}$ & $.381^{*}$ \\
& $(.169)$ & $(.151)$ & $(.097)$ & $(.186)$ & $(.171)$ \\
Revisionist & $1.43^{*}$ & $1.55^{*}$ & $1.60^{*}$ & $1.42^{*}$ & $1.42^{*}$ \\
& $(.314)$ & $(.252)$ & $(.167)$ & $(.289)$ & $(.318)$ \\
Constant & .028 & .083 & -.007 & .073 & .031 \\
& $(.069)$ & $(.085)$ & $(.065)$ & $(.075)$ & $(.080)$ \\
\hline N & 16149 & 16640 & 16287 & 16640 & 16149 \\
Log-likelihood & -263.67 & -275.21 & -259.72 & -275.08 & -263.65 \\
\hline \hline
\end{tabular}

Table 3: Target's Outcome Utilities 


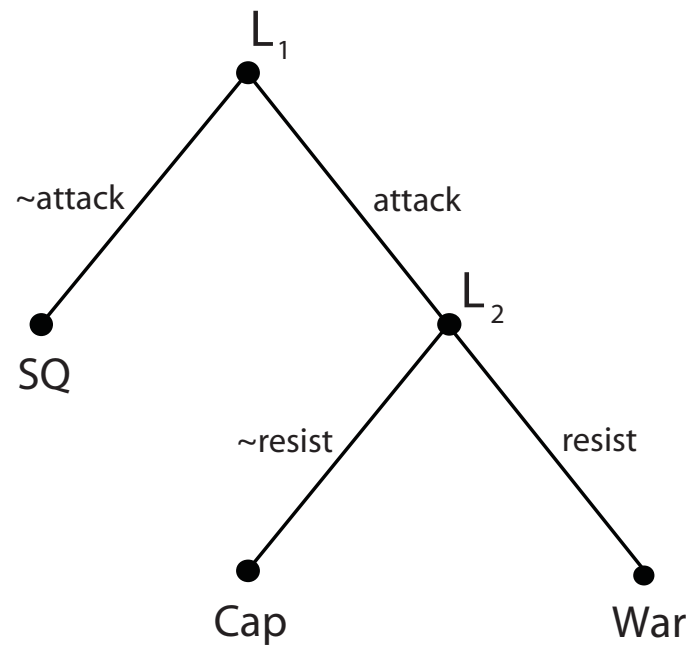

(A)

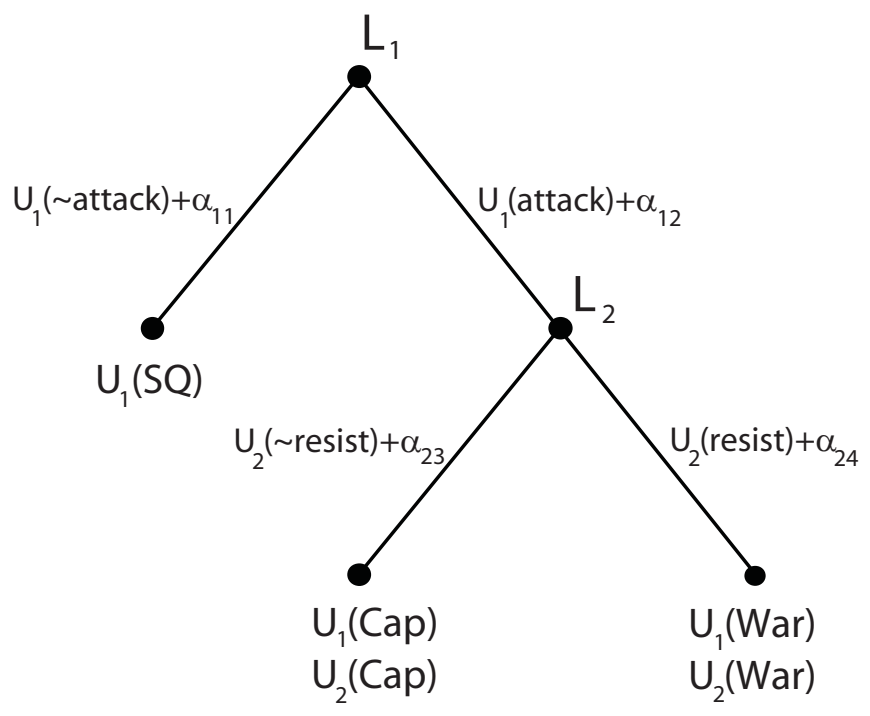

(B)

Figure 1: A Model of a Crisis Interaction between the Leaders of Two Countries 


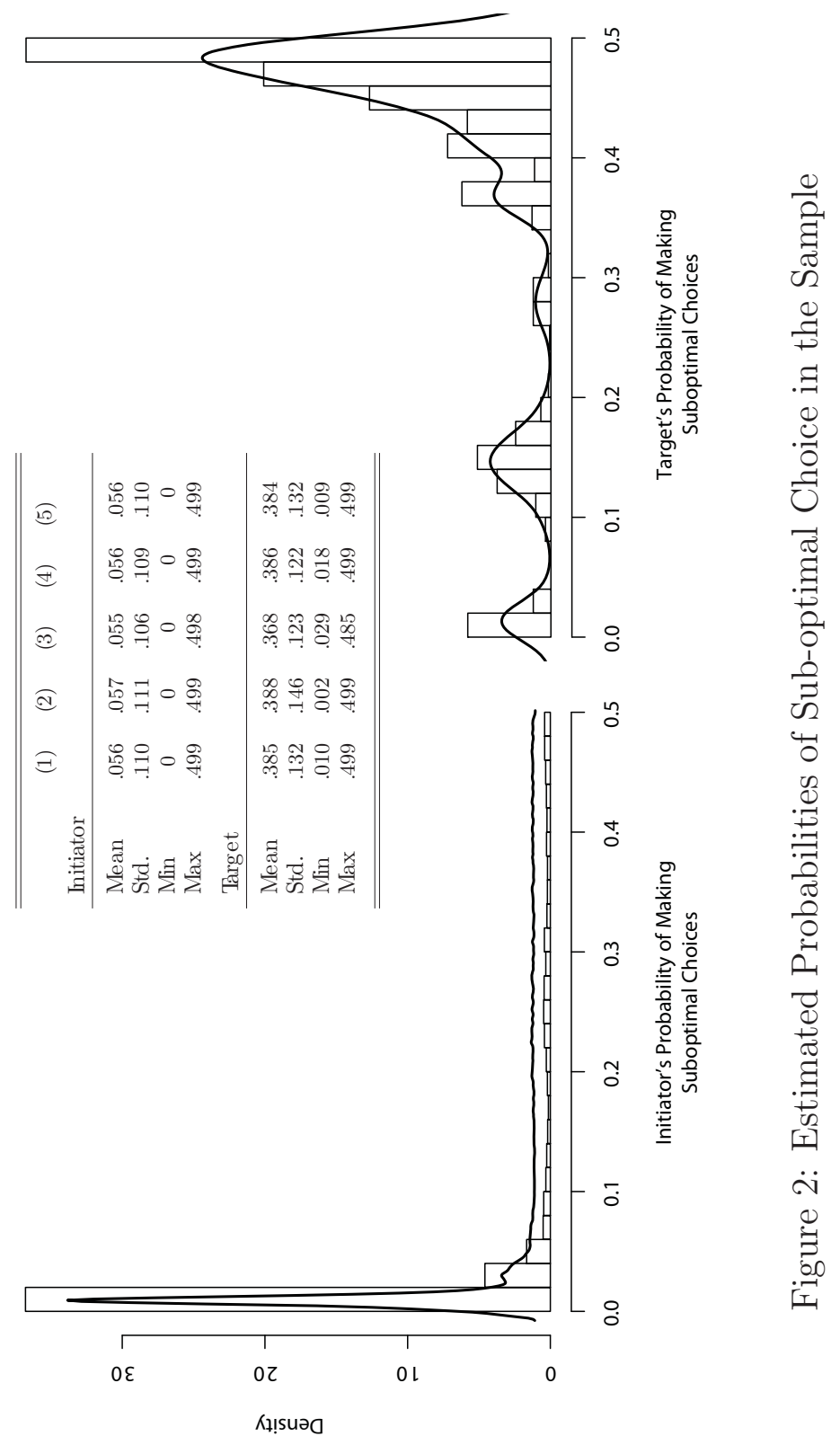

